\title{
PENGARUH KOMUNIKASI INTERPERSONAL IBU DAN ANAK TERHADAP KEMAMPUAN BERBICARA ANAK Studi Ex Post Facto Anak Usia 4-5 Tahun Pada Kelompok A Taman Kanak Kanak Islam Kelurahan Pondok Bambu Jakarta Timur
}

\author{
EVA RIZA,S.Pd., M.Pd ${ }^{1}$
}

\author{
${ }^{1}$ Program studi PG- PAUD, Fakultas Ilmu Pendidikan Universitas MH. Thamrin \\ Alamat Korespondensi : \\ Program studi Fakultas Ilmu Pendidikan, Universitas MH.Thamrin, Jln. Raya Pondok Gede No. 23-25 Kramat Jati \\ Jakarta Timur 13550Telp : 8096411 ext 1208
}

\begin{abstract}
Abstrak: Tujuan penelitian ini adalah untuk mengkaji pengaruh komunikasi interpersonal terhadap kemampuan berbicara anak usia 4-5 Tahun di Kelompok A Taman Kanak-kanak di Kelurahan Pondok Bambu semeter kedua tahun akdemik 2009/2010, dengan menggunakan metode expost facto dengan sample 48 orang siswa. Hasil penelitian menunjukkan bahwa terdapat pengaruh positif komunikasi interpersonal ibu dan anak terhadap kemampuan berbicara anak usia 4-5 tahun. Hal ini menunjukkan bahwa jika komunikasi interpersonal ibu dan anak ditingkatkan, maka kemampuan berbicara anak juga akan meningkat. Demikian juga sebaliknya, apabila komunikasi interpersonal ibu dan anak berkurang, maka kemampuan berbicara anak juga akan rendah.
\end{abstract}

Kata kunci: komunikasi interpesonal, kemampuan berbicara anak, Taman Kanak-kanak.

\section{Pendahuluan}

Bahasa merupakan alat komunikasi yang memegang peranan penting dalam kehidupan manusia dalam berkomunikasi antara individu yang satu dengan individu yang lainnya. Bahasa merupakan sarana untuk menyampaikan pesan berupa pikiran dan perasaan yang ada di dalam diri individu tersebut. Selain itu, bahasa menunjukkan perbedaan manusia dengan mahluk lainnya. Manusia dapat menyampaikan pikirannya melalui bahasa yaitu melalui berbicara, sedangkan hewan tidak dapat mengungkapkan ke-inginannya dalam bentuk kata-kata.

Pentingnya bahasa ini juga dikemukakan oleh Suriasumantri (2003: 171) bahwa keunikan manusia sebenarnya terletak pada kemampuan berbahasanya, bukanlah terletak pada kemampuan berpikirnya sebagaimana yang diyakini selama ini, tanpa mempunyai kemampuan berbahasa ini maka kegiatan ber-pikir secara sistematis dan teratur tidak mungkin dapat dilakukan. Dengan kata lain kegiatan berpikir anak diwujudkan dalam berbahasa, sehingga kemampuan anak dalam berbahasa juga akan mendorong anak dalam berpikir secara sistematis. Sejalan dengan itu Piaget dalam Feeney (2006:115-116) mengemukakan bahwa bahasa mempengaruhi perkembangan berpikir dan sebaliknya perkem-bangan berpikir kognitif juga me-ngembangkan bahasa.

Keterkaitan penguasaan bahasa tidak hanya menstimulasi kegiatan anak dalam berpikir tetapi juga ber-sosialisi dengan lingkungannya dan untuk pengambilan keputusan. Sedangkan penguasaan bahasa pada usia dini menurut Essa (2003: 328) merupakan evolusi perkem-bangan keterampilan bahasa anak yang sangat penting bagi per-kembangan anak. Makin mampu anak melakukan tugas-tugas bahasa yang kompleks pada saat usia dini, maka makin mempermudah anak tersebut dalam penguasaan makna dan tata bahasa selanjutnya.

Untuk itu, anak usia dini memerlukan respons atau dukungan dalam menggunakan bahasa dalam konteks kehidupan sehari-hari. Selain itu dalam berkomunikasi anak me-merlukan model sehingga ke-mampuan berbicara anak akan mangkin baik. Model yang dimaksud adalah ibu karena mulai dari dalam kandungan antara ibu dan anak telah memiliki kedekatan. Berdasarkan hasil penelitian yang dilakukan oleh Tubbs dan Moss dalam Tarigan (2005, 2.3) dikatakan bahwa sekitar $75 \%$ waktu manusia setiap harinya dihabiskan untuk berkomunikasi. Untuk itu keterampilan bahasa yang dapat dikem-bangkan pada usia dini adalah berbicara maka stimulasi kegiatan berbicara melalui komunikasi inter-personal ibu dan anak. Komunikasi interpersonal ini merupakan peluang yang sangat berharga dalam upaya melatih anak berbicara secara in-formal. Karena komunikasi inter-personal memiliki aspek antara lain bertatap muka secara langsung, rasanya nyaman dalam berkomu-nikasi, saling memberi dukungan, rasa positif terhadap lawan bicara, dan adanya kesetaraan dalam berkomunikasi. 
Namun kenyataan yang terjadi di dalam masyarakat saat ini masih banyak orangtua khususnya ibu menjadikan anak sebagai pendengar, jarang diberikan kesempatan ber-tanya. Orangtua beranggapan bahwa anak yang baik adalah anak yang patuh mengikuti segala sesuatu yang diucapkan orang tuanya. Ukuran kepatuhan anak adalah seberapa banyak anak tersebut mendengarkan ucapan orangtua nya, tambahan lagi anak jarang diberikan kesempatan untuk bertanya, menyampaikan ide atau gagasannya. Ini menunjukkan bahwa waktu komunikasi yang sebagian besar terjadi dalam ke-hidupan manusia tersebut belum mempunyai sumbangan yang berarti pada kemampuan berbicara anak, padahal kesempatan untuk menyam-paikan ide dan gagasan merupakan bagian penting dalam upaya men-stimulasilasi anak untuk berbicara.

Berdasarkan latar belakang masalah tersebut, peneliti tertarik untuk melakukan penelitian tentang Pengaruh Komunikasi Interpersonal Ibu dan Anak terhadap Kemampuan Berbicara Anak Usia 4-5 Tahun di Taman Kanak-Kanak Islam pada Kelompok A, di Kelurahan Pondok Bambu.

\section{Perumusan Masalah}

Apakah terdapat pengaruh komu-nikasi interpersonal ibu dan anak terhadap kemampuan berbicara anak usia 4-5 tahun?

\section{Kajian Literatur}

\section{Kemampuan Berbicara Anak Usia 4-5 Tahun}

Rentangan usia perkembangan merupakan batasan kemampuan berbahasa anak. Menurut Wortham (2005: 18) kemampuan mengacu kepada pengetahuan dan kete-rampilan yang dimiliki anak pada saat itu. Kemampuan tersebut berupa kemampuan motorik, kemampuan berbahasa, kemampuan sosial dan keterampilan kognitif. Sebagian ahli mengurutkan penguasaan kemam-puan berbahasa ke dalam urutan penguasaannya menyimak, berbi-cara, membaca dan menulis. Semen-tara itu kemampuan berbahasa menurut Mc.Devitt (2004: 286) adalah bahasa reseptif yaitu kemampuan untuk memahami apa yang didengar (menyimak), dan dibaca (membaca) seseorang yang melibatkan pemahaman bahasa. Sedangkan bahasa ekspresif adalah kemampuan untuk mengungkapkan bahasa secara efektif baik dalam bentuk lisan (berbicara) ataupun tulisan (menulis).

Dari sudut pandang isi pembicaraan Suhartono (2005:20) mengemukakan bahwa berbicara dapat diartikan sebagai suatu penyampaian maksud ide, pikiran, gagasan, atau isi hati. Sementara itu Tarigan (2008:16) tidak hanya mengemukakan isi pembicaraan tetapi berbicara adalah kemampuan mengucapkan bunyi artikulasi atau kata-kata untuk mengekspresikan, menyatakan, atau menyampaikan pikiran, gagasan, dan perasaan. Secara lengkap Mayuni (2007: 33) mengemukakan bahwa kemampuan berbicara meliputi penguasaan tata bahasa dan kosa kata, pelafalan, kelancaran, pemahaman tentang konteks, dan pelibatan komponen nonlinguistik, seperti bahasa tubuh, suara, dan se-bagainya.

Menurut Jalongo (2007: 64) mengemukakan bahwa anak usia 4-5 tahun telah mampu menggunakan kalimat lengkap, pengucapan dan tata bahasa me-ngalami peningkatan, kosa kata berkisar antara 1400 sampai dengan 1600 kata. Secara sosial anak mencari cara untuk mengoreksi salah pengertian, mulai menyesuaikan pembicaraan sesuai dengan kebutuhan lawan bicara, perselisihan dengan teman sebaya diselesaikan melalui kata-kata dan mengajak bermain merupakan ciri umum anak seusia ini.

Berdasarkan uraian di atas, maka dapat dideskripsikan bahwa kemampuan berbicara anak usia 4-5 tahun adalah adalah kemampuan atau kesanggupan anak dalam menggunakan aspek-aspek dalam berbicara yang meliputi : (1) peng-ucapan, (2) tata bahasa, (3) kosa kata (4) ide atau gagasan yang terjadi dalam aktivitas sehari-hari secara alamiah sesuai dengan usia dan karakteristik anak.

\section{Komunikasi Interpersonal Ibu dan Anak}

Komunikasi menurut Efendi (2001:10) ditinjau dari asal kata yaitu dalam bahasa Inggris communication berasal dari kata Latin communicatio dan ber-sumber dari kata communis yang berarti sama atau kesamaan makna. Komunikasi adalah proses mengubah perilaku orang lain karena terjadinya kesamaan makna. Kesamaan makna terjadi sebagai akibat proses komunikasi ini merupakan fungsi dari komunikasi. Menurut Verderber dalam Mulyana (2007:5) komunikasi mempunyai dua fungsi yaitu fungsi sosial dan fungsi pengambilan keputusan. Pertama fungsi sosial, yakni untuk tujuan kesenangan, untuk menunjukkan ikatan dengan orang lain, mem-bangun 
dan memelihara hubungan. Kedua fungsi pengambilan ke-putusan, yakni memutuskan untuk melakukan atau tidak melakukan sesuatu pada saat tertentu.

Menurut pendapat Taylor dan Altman yang dikutip De Vito dalam Wiryanto (2004:37-38) dengan berkembangnya hubungan sosial, maka keluasan dan kedalaman komunikasi antara pribadi akan meningkat. Tingkat keluasan yang dibicarakan dalam proses komunikasi antar pribadi dapat diilustrasikan dengan lingkaran. Lingkaran dalam memperlihatkan hubungan yang sangat dekat, misalnya di antara saudara kandung, orang tua, dan sahabat karib.

Komunikasi interpersonal juga dikemukakan oleh John (2002:234) bahwa komunikasi interpersonal ialah komunikasi yang terjadi antara dua orang yang telah lama berhubungan; orangorang tersebut dalam ber-hubungan berkomunikasi antar pribadi yaitu meliputi antara anak dengan orang tua, pekerja dengan pemberi kerja, diantara dua saudara, antara guru dan murid, antara sepasang kekasih, diantara dua sahabat dan sebagainya. Sementara itu Senjaya (2007:2.1) adalah suatu proses pertukaran makna antara orang-orang yang saling berkomu-nikasi. Proses mengacu pada per-ubahan dan tindakan yang ber-langsung terus menerus.

Sementara itu Mulyana (2007: 81) mengemukakan bahwa komunikasi interpersonal adalah komunikasi antara orang-orang secara tatap muka, yang memungkinkan setiap pesertanya menangkap reaksi orang lain secara langsung, baik secara verbal ataupun nonverbal. Dalam kaitan itu pula maka menurut Harjana (2003:88-90) komunikasi interper-sonal mem-punyai ciriciri yang tetap sebagai berikut: (1) bersifat verbal dan non verbal; (2) meliputi prilaku tertentu, komunikasi yang berproses pengem-bangan; (3) mengandung umpan balik, interaksi dan koherensi; (5) berjalan menurut peraturan tertentu; (6) berupa kegiatan aktif; dan (7) saling mengubah.

Sehubungan komunikasi inter-personal antara ibu dan anak, maka menurut Rakhmat (2007:129133) faktor-faktor yang menumbuhkan hubungan interpersonal yang baik adalah: (1) percaya, (2) sikap suportif, dan (3) sikap terbuka. Dalam kaitan komunikasi inter-personal Kumar dalam Wiryanto (2004: 3.6) mengemukakan lima ciri yaitu: (1) Keterbukaan (openess) yaitu kemauan mananggapi dengan senang hati informasi yang diterima di dalam menghadapi hubungan antar pribadi; (2) empati (emphaty) yaitu merasakan apa yang dirasakan orang lain; (3) dukungan (supportiveness) yaitu situasi yang terbuka untuk mendukung komuni-kasi berlangsung efektif; (4) rasa positif (positiveness) yaitu seorang harus memiliki perasaan positif terhadap dirinya, mendorong orang lain lebih aktif berpartisipasi, dan menciptakan situasi komunikasi kondusif untuk interaksi yang efektif; dan (5) pengakuan secara diam-diam bahwa kedua belah pihak meng-hargai, berguna dan mempunyai sesuatu yang penting untuk disumbangkan.

Berdasarkan uraian di atas, dapat dideskripsikan bahwa komunikasi interpersonal ibu dan anak adalah pertukaran informasi yang bersifat pribadi antara ibu dan anak dalam aktivitas sehari-hari dalam suasana (1) bertatap muka, (2) keterbukaan, (3) dukungan, dan (4) kesetaraan.

\section{Metode Penelitian}

Penelitian ini dilaksanakan di Taman Kanak-Kanak Islam Kelurahan Pondok Bambu pada Kelompok A usia 4-5 tahun, Jakarta Timur pada bulan Januari sampai dengan bulan Februari semester II Tahun Pelajaran 2009/2010. Metode penelitian yang digunakan adalah Ex Post Facto yaitu penelitian ini mencoba menentukan suatu sebab dari sesuatu yang sudah terjadi. Populasi penelitian ini keseluruhan berjumlah 57 siswa, terpilih sampel sebsar 48 siswa.

Pengumpulan data komunikasi interpersonal ibu dan anak dilakukan dengan menggunakan kuesioner/ angket model skala Likert dan data kemampuan berbicara anak meng-gunakan assesmen yaitu observasi dalam bentuk Ceklis. Selanjutnya data dianalisis dengan menggu-nakan statistik deskriptif mencari rata-rata, median, modus, standar deviasi dan statistik inferensial terdiri dari uji normalitas menggunakan uji Liliefors, uji homogenitas menggu nakan uji Barlett. Hasil pengujian hipotesis menunjukkan bahwa diperoleh $t_{\text {hitung }}=3,475>t_{\text {tabel }}=2,49$ pada taraf signifikansi $\alpha \square=0,05$. Artinya, $\mathrm{H}_{0}$ yang menyatakan tidak terdapat pengaruh komunikasi interpersonal ibu dan anak terhadap kemampuan berbicara anak usia 4-5 tahun ditolak, konsekuensinya $\mathrm{H}_{1}$ diterima. 


\section{Hasil Penelitian Dan Pembahasan}

Data penelitian ini terdiri dari: kemampuan berbicara anak $(\mathrm{Y})$ sebagai variabel terikat, dan Komunikasi Interpersonal Ibu dan Anak (X) sebagai variabel bebas. Untuk masing-masing variabel, di bawah ini akan disajikan nilai rata-rata, simpangan baku, median, modus, distribusi frekuensi, serta histogram dari setiap variabel.

\section{Kemampuan berbicara anak}

Berdasarkan data penelitian untuk variabel kemampuan berbicara anak diperoleh rentang skor empiris 11 dengan skor terendah 81, dan skor tertinggi 92. Dari analisis data diketahui skor ratarata sebesar 86,13 , simpangan baku 2,52 , median 86 , modus 87 , banyaknya kelas 7 dan panjang kelas 2.

Berdasarkan perhitungan dipe-roleh nilai frekuensi dilihat bahwa 31,25\% dari jumlah respon-den memperoleh skor kelompok rata-rata dari skor kemampuan berbicara anak. Sebagaimana diketahui skor rata-ratanya sebesar 86,13. Respon-den yang memperoleh skor di bawah harga kelompok ratarata adalah 39,58 \%, dan responden yang memperoleh skor di atas harga kelompok rata-rata adalah $29,15 \%$.

\section{Komunikasi Interpersonal Ibu dan Anak}

Berdasarkan data penelitian, untuk variabel komunikasi interper-sonal ibu dan anak, diperoleh rentang skor empiris 21 dengan skor teren-dah 65 dan skor tertinggi 86. Dari analisis data didapatkan harga rata-rata sebesar 75,13, simpangan baku 4,97, median 76,00, modus 72, banyaknya kelas 7 dan panjang kelas 3 .

\section{Pengujian Hipotesis dan Pembahasan}

Setelah dilakukan uji persyaratan analisis, ternyata semua skor setiap variabel penelitian memenuhi persya-ratan untuk dilakukan pengujian statistik lebih lanjut yaitu pengujian hipotesis. Dalam hipotesis penelitian, yaitu: terdapat pengaruh positif antara kemampuan berbicara anak. Berikut ini disajikan pembahasan hasil pengujian hipotesis penelitian yang menggunakan uji-t terhadap pengaruh komunikasi interpersonal ibu dan anak terhadap kemampuan berbicara anak usia 4-5 tahun.

Berdasarkan uji keberartian korelasi antara pasangan skor komunikasi interpersonal ibu dan anak (X) terhadap kemampuan berbicara anak $(\mathrm{Y})$ sebagaimana terlihat pada Tabel diperoleh $\mathrm{t}_{\text {hitung }}=$ $2,411>\mathrm{t}_{\text {tabel }}=1,68$ pada taraf signifikansi $\alpha \square=0,051$, maka dapat disimpulkan bahwa koefisien korelasi $\mathrm{r}_{\mathrm{y} 1}=0,335$ signifikan. Dengan demikian, $\mathrm{H}_{0}$ yang mengatakan tidak terdapat pengaruh komunikasi interpersonal ibu dan anak terhadap kemampuan berbicara anak ditolak, konsekuensinya $\mathrm{H}_{1}$ diterima. Berdasarkan hasil penelitian menyimpulkan bahwa terdapat pengaruh positif komunikasi interpersonal ibu dan anak terhadap kemampuan berbicara anak. Hal ini berarti bahwa semakin tinggi komunikasi interpersonal ibu dan anak, maka semakin tinggi kemam-puan berbicara anak.

Hasil analisis juga me-nunjukkan koefisien determinasinya sebesar 0,112. Ini berarti $11,20 \%$ varians kemampuan berbicara anak dijelaskan oleh variabel komunikasi interpersonal ibu dan anak

\section{kesimpulan}

Dengan demikian dapat disimpulkan bahwa komunikasi interpersonal ibu dan anak mempunyai pengaruh yang positif terhadap kemampuan berbicara anak. Hal ini menunjukkan bahwa jika komunikasi interpersonal ibu dan anak ditingkatkan, maka kemampuan berbicara anak juga akan meningkat. Demikian juga sebaliknya, apabila komunikasi interpersonal ibu dan anak berkurang, maka kemampuan berbicara anak juga akan rendah.

Berdasarkan temuan hasil penelitian ini memberikan suatu gambaran mengenai pengaruh komunikasi interpersonal ibu dan anak terhadap kemampuan berbicara anak usia 4-5 tahun. Berdasarkan hasil penelitian ini diketahui bahwa dengan komunikasi interpersonal antara ibu dan anak dapat mening-katkan kemampuan berbicara anak. Hal ini berarti bahwa semakin sering ibu melakukan komunikasi interper-sonal dengan anak maka kemam-puan berbicara anak akan meningkat pula.

Berdasarkan hal-hal yang dike-mukakan di atas, maka sebagai implikasi dari hasil penelitian ini sebaiknya ibu mengupayakan aktivitas berbahasa melalui komu-nikasi interpersonal antara lain: 
Pertama, menciptakan kegiatan keluarga dalam suasana penuh kebersamaan antara orang tua dan anak khususnya ibu seperti berbelanja, masak, makan bersama, shalat berjamaah, rekreasi keluarga, dan menonton bersama. Melalui kegiatan tersebut akan menimbulkan kedekatan dan keterbukaan antara ibu dan anak. Ibu dapat memberikan saran yang berguna bagi anak dan menanyakan anak tentang pengalaman dari kegiatan tersebut. Terjadinya komunikasi yang baik akan mempererat hubungan antara ibu dan anak, sehingga diharapkan komunikasi interpersonal antara ibu dan anak akan semakin meningkat dan berkualitas.

Kedua, saat anak berbicara berikan jawaban yang sesuai dengan kemampuan dan tahap perkem-bangan anak, dengan kata lain jawaban yang diberikan oleh ibu harus memenuhi rasa keingintahuan anak, yang diwujudkan oleh anak melalui bertanya.

Ketiga, berikan reward atau penguatan jika anak dapat me-nyampaikan sesuatu dengan pengucapan dan bahasa yang benar. Sebaliknya berikan stimulasi dan perbaikan jika anak kurang tepat dalam pengucapannya, misalnya ibu mengulangi kembali kata-kata ter-sebut dengan pengucapan yang benar.

Keempat, sebaiknya ibu mem-budayakan kegiatan bercerita kepada anak, misalnya kisah tentang nabi dan para sahabatnya atau men-ceritakan tentang pengalaman ibu diwaktu kecil. Selain itu berikan kesempatan kepada anak untuk bercerita tentang pengalamannya di sekolah, cerita tentang rekreasi, dan lain-lain. Kegiatan ini dapat dilakukan sebelum anak tidur, setelah anak pulang dari sekolah, rekreasi atau bepergian. Tanpa disadari melalui kegiatan tersebut akan memper-lancar kemampuan berbicara anak serta menambah kosa kata anak. Oleh sebab itu budaya bercerita bersama anak perlu ditingkatkan.

Kelima, melibatkan anak dalam diskusi keluarga, misalnya dalam penataan rumah, menentukan makanan kesukaan, tempat rekreasi, binatang peliharaan, dan lain sebagainya. Seorang anak yang sudah memiliki kemampuan untuk berbicara dapat menyampikan ide, atau pendapat sesuai dengan tahap perkembangannya. Selain itu setiap anak juga berhak untuk menge-mukakan pendapatnya. Dengan adanya keterbukaan antara ibu dan anak akan meningkatkan kemam-puan berbicara anak.

\section{Saran}

Berdasarkan kesimpulan dan implikasi penelitian yang telah dikemukakan di atas, maka untuk mengantisipasi hal-hal tersebut dan mencapai maksud dan tujuan pengaruh komunikasi interpersonal ibu dan anak terhadap kemampuan berbicara anak, peneliti mengajukan saran kepada ibu-ibu yang memiliki anak usia 4-5 tahun, antara lain:

1. Perlu peningkatan kegiatan-kegiatan yang dapat mening-katkan frekuensi interaksi antara ibu dan anak.

2. Diharapkan kepada ibu agar bisa menjadi model yang baik dalam proses meningkatkan kemam-puan berbicara anak.

3. Diharapkan kepada ibu-ibu agar selalu meningkatkan kemam-puannya dalam memahami bahasa anak, sehingga dapat menjawab rasa keingintahuan anak sesuai dengan tahap perkembangan anak.

4. Perlu meningkatkan budaya demokrasi berpendapat di dalam keluarga tanpa memandang usia anggota dalam keluarga.

5. Diharapkan kepada kedua orang tua khususnya ibu, agar memberikan kesempatan kepada anak untuk berinteraksi dengan lingkungan yang lebih luas, misalnya memberikan kesempatan bagi anak untuk bermain dengan teman sebayanya. Melalui interaksi dengan teman sebayanya, secara tidak langsung akan menambah kosa kata anak, dan belajar memberi dan menerima pendapat dengan orang lain.

\section{Daftar Pustaka}

Akbar-Hawadi, Reni Psikologi Perkembangan Anak, Mengenal Sifat, Bakat, dan Kemampuan Anak Jakarta: Grasindo, 2001.

Effendy, Onong Uchjana Ilmu Komunikasi Teori dan Praktek Bandung: PT Remaja Rosdakarya, 2001. 
Essa, Eva L. Introduction to Early Childhood Education Annoted Student's Edition Canada:Thomson Delmar Learning, 2003.

Feeney, Stephanie Doris Christensen \& Eva Moravcik, Who Am I in the Lives of Children? Seventh Edition New Jersey: Pearson Merrill Prentice Hall, 2006.

Hardjana, Agus M. Komunikasi Intrapersonal \& Interpersonal Jakarta: Kanisius, 2003.

Jalongo, Mary Renck Early Chilhood Language Arts Fourth Edition Boston: Pearson, 2007.

John, Stephen Little Theories of Communication Seventh Edition Stamford: Wadsworth Thomas learning, 2002.

Marat, Samsunuwiyati "Perkembangan Bahasa Seorang Anak: Suatu Tinjauan Psikolinguistik" Bunga Rampai Psikologi Perkembangan Pribadi dari Bayi Sampai Lanjut Usia, (Jakarta: Universitas Indonesia Press, 2001.

Mayuni, Ilza Peningkatan Mutu Guru Bahasa Inggris Melalui Pendidikan Dalam Jabatan Bandung: Lubuk Agung, 2007.

Mulyana, Dedy. Ilmu Komunikasi:Suatu Pengantar (Bandung: Penerbit PT Remaja Rosdakarya, 2007.

Senjaya, Sasa Djuarsa Teori Komunikasi Jakarta: Universitas Terbuka, 2007

Suriasumantri, Jujun S. Filsafat Ilmu: Sebuah Pengantar Populer Jakarta: Pustaka Sinar Harapan, 2003.

Tarigan, Djargo dkk, Pendidikan Bahasa dan Sastra Indonesia di Kelas Rendah Edisi Kesatu (Jakarta: Universitas Terbuka, 2005.

Tarigan, Guntur Berbicara sebagai Keterampilan Berbahasa Bandung: Angkasa, 2008.

Suhartono, Pengembangan Keterampilan Berbicara Anak Usia Dini Jakarta: Departemen Pendidikan Nasional Dikti, Dirjen Pembinanan Tenaga Kependidikan dan Tenaga Perguruan Tinggi, 2005.

Wiryanto, Pengantar Ilmu Komunikasi Jakarta: PT Gramedia Widiasarana Indonesia), 2004. 